\title{
Nucleic Acid Synthesis Inhibitor
}

National Cancer Institute

\section{Source}

National Cancer Institute. Nucleic Acid Synthesis Inhibitor. NCI Thesaurus. Code C1661.

A pharmacological agent that inhibits DNA replication or RNA synthesis. 